\title{
Study of Effects of Photodynamic Therapy (PDT), in Scar-Induced Skin Wounds in Rats Wistar: The New Clinical Perspective for Ulcers
}

\author{
Marcus Vinicius de Mello Pinto1,2, Aline Ronis Sampaio², Reggiani Vilela Gonçalves3, \\ Carlos Eduardo Tenório da Veiga ${ }^{2,4}$, Lamara Laguardia Valente Rocha ${ }^{5}$, \\ Daniel Almeida da Costa ${ }^{5,6}$, Lina Claudia Pereira Lopes ${ }^{6,7}$, Rafael Batista Ferreira ${ }^{6,7}$, \\ Pamela Mara Cainelli Valim ${ }^{6,7}$, Kellen Regina Rodrigues Chaveiro ${ }^{6,7}$, Elias Sobreira Sathler ${ }^{6,7}$, \\ Richard Raphael Borges Tavares Vieira6,7, Isabela Nardoni Bernardes,7 \\ ${ }^{1}$ Medical School of the University of Buenos Aires, Bueinos Aires, Argentina \\ ${ }^{2}$ The Cellurare Institute Center of Laser Treatment and Cell Therapy, Petrópolis, Brazil \\ ${ }^{3}$ Department of Cellular and Structural Biology of Federal University of Viçosa, Viçosa, Brazil \\ ${ }^{4}$ Clinical Hospital ofCorrêas, Rio de Janeiro, Brazil \\ ${ }^{5}$ The Medical School at the Health Sciences Institute of the University Center of Caratinga, Caratinga, Brazil \\ ${ }^{6}$ The Medical School at the Center of Higher Education of Valenca, Valenca, Brazil \\ ${ }^{7}$ Luiz Gioseffi Jannuzzi School Hospital of the Dom Andre Arcoverde Foundation, Valenca, Brazil \\ Email: orofacial_1@hotmail.com, alronis@ig.com.br, reggysvilela@yahoo.com.br, drcarlostenorio@yahoo.com.br, \\ lamara.laguardia@gmail.com, acosttta@icloud.com, linalopes217@gmail.com, belinhax@hotmail.com, rbf_br@hotmail.com, \\ pamela.valim@yahoo.com.br, kellenchaveiro@hotmail.com, essathler@hotmail.com,rrbtv@hotmail.com
}

How to cite this paper: de Mello Pinto, M.V., Sampaio, A.R., Gonçalves, R.V., da Veiga, C.E.T., Rocha, L.L.V., da Costa, D.A., Lopes, L.C.P., Ferreira, R.B., Valim, P.M.C., Chaveiro, K.R.R., Sathler, E.S., Vieira, R.R.B.T. and Bernardes, I.N. (2017) Study of Effects of Photodynamic Therapy (PDT), in Scar-Induced Skin Wounds in Rats Wistar: The New Clinical Perspective for Ulcers. Modern Research in Inflammation, 6, $1-8$.

https://doi.org/10.4236/mri.2017.61001

Received: December 3, 2016

Accepted: February 25, 2017

Published: February 28, 2017

Copyright $\odot 2017$ by authors and Scientific Research Publishing Inc. This work is licensed under the Creative Commons Attribution International License (CC BY 4.0).

http://creativecommons.org/licenses/by/4.0/

\section{Abstract}

Photodynamic therapy today is becoming an important role in the healing of lacerated tissues, since it has therapeutic resources capable of accelerating this process. One treatment option is the clinical phototherapy, and Photodynamic Therapy (PDT) is being widely used. This study aims to evaluate the effect of PDT on the healing of skin wounds in rats. We used a sample of 39 male rats Wistar divided into three groups, a control, a PDT-treated green and red with the last PDT. After 24 hours before the surgical incisions, PDT was used in both groups for 6 minutes and was evaluated in histological level, the inflammatory reaction and the repair process. The results showed that the granulation tissue was more developed in the irradiated group than in the control group and the amount of chronic inflammatory cells (monocytes, macrophages, lymphocytes and plasma cells) predominated with green phototherapy. The epithelialization in the wound margins and scarring with better quality occurred with red PDT $(640 \mathrm{~nm})$, which the higher deposition was of collagen. However, phototherapy not collimated of $640 \mathrm{~nm}$ (red) resulted in better anti-inflammatory effects. Given these answers with phototherapy not collimated green $(525 \mathrm{~nm})$ and red $(640 \mathrm{~nm})$, we conclude that the use of these

\section{Open Access}


wavelengths is possible with benefits, mainly with red LED.

\section{Keywords}

Healing, Photodynamic Therapy (PDT), Light Emitting Diodes (LEDs), Úlcer

\section{Introduction}

Diabetes mellitus is one of the most prevalent diseases worldwide, and Type 2 affects the high percentile of the elderly population, leading to complications that can occur over time and can affect various organs such as kidneys, eyes, vessels, peripheral nerves, and the skin [1].

Peripheral neuropathy and angiopathy are complications that culminate in the appearance of plantar ulcers in these patients, a condition known as "diabetic foot", which makes them very vulnerable to difficult-to-heal lesions that serve as a gateway to infections [2].

In this context, cutaneous ulcers are very common in clinical practice and directly affect patients' quality of life, resulting in high cost with treatments and are accompanied by a delicate prognosis, given the difficulty in the course of this pathology and clinical treatment, which is faced with the growing problem of bacterial multidrug resistance that has significantly increased infection rates in these ulcers. Failure to heal often necessitates the use of several classes of antibiotics, further aggravating the problem [3].

According to the O'Neill report, there is a dire and imminent prediction that by 2050, antibiotic resistance could cause an additional 300 million deaths and cost $\$ 100$ trillion, as the antibiotic era experiences a real catastrophe of multidrug resistance of new classes of antibiotics. These data's needs of investment on the discovery of alternative antimicrobial technologies are evident to the bacterias that are not able to defend themselves, guaranteeing efficacy regardless of bacterial resistance status [4].

The International Diabetes Federation (IDF) and the World Health Organization (WHO) highlight the problem by ratifying that more than half of lower limb amputations could be prevented if there is adequate prevention and care. Therefore, new clinical methods should be developed to suppress amputations [5].

Data from the literature demonstrate better results in the recovery of diabetic foot when approached together by clinicians and surgeons, performing debridement and antimicrobial therapy. However, new research is extremely necessary for real advances in treatment [5].

Photodynamic therapy (PDT) is considered a promising new treatment method for the eradication of microorganisms including bacteria, fungi and viruses and has been clinically approved for the treatment of some infectious skin diseases such as acne and viral warts. In addition, several studies have confirmed the efficacy of PDT in the treatment of bacterial infections and their biofilms, acting at multiple points such as membrane phospholipids, proteins and nucleic acids, a 
mechanism that may explain the elimination of resistant microorganisms and prevent the selection of strains [4] [6] [7].

The exact mechanism of action of PDT is not yet fully understood, although it has already been investigated in some detail. However, it is already known that it involves the absorption of a light photon with wavelength corresponding to the band of a photosensitizer, which is then excited for a short action on the scale of nanoseconds to microseconds. When longer half-life is achieved, it allows the formation of reactive oxygen species (ROS) that can damage almost all types of microbial biomolecules, leading to cell lysis [4] [8].

A clinical study performed with PDT for treatment of Pseudomonaaeruginosa infection in mice demonstrated that the wound healing rate was significantly faster than in the silver nitrate treated control group [9]. In addition, an earlier study showed a rate of eradication of bacteria such as Staphylococcus aureus, methicillin-resistant Staphylococcus aures, Streptococcus mutans, Streptococcus sobrinus and Streptococcus sanguine is over 95\% with PDT [10].

The use of low-cost PDT protocols has been explored for the treatment of chronic ulcers and diabetic foot ulcers, including a recent case report showing the recovery of two patients with chronic ulcers and osteomyelitis with indication of amputations, who responded positively to PDT And thus avoided amputation. However, despite the great potential, PDT is still little used in clinical practice for the treatment of diabetic foot, probably because of lack of knowledge on this subject [11]. Due to this, in 2014, a large clinical study was performed to obtain statistically reliable results, which would allow evaluating the efficacy of PDT as the treatment of choice for diabetic foot for amputation [12].

Light emitting diodes (LEDs) constitute a specific type of PDT emitted and used at a wavelength ranging from $405 \mathrm{~nm}$ (blue) to $960 \mathrm{~nm}$ (infrared), photo stimulating the cell and acting on the mitochondria, in the synthesis of ATP, Proteins such as collagen, elastin and others. By varying the wavelength, it is also seen an antimicrobial, anti-inflammatory and biological action [13] [14].

Failache and Geido (2006) compared cutaneous lesions of diabetic rats treated only with PDT with LED treated, finding better results with the seconds than with PDT. The variations of the results are related to the PDT wave lengths, which is determinant in its mechanism of action, relating directly to the biomolecules involved [15].

Being a relatively new application of this technology, the specific therapeutic effects are still under investigation as to their actual results. Thus, this in vivo study was conducted with the objective of evaluating the effects of LED type PDT on the healing of cutaneous wounds in Wistar rats.

\section{Material and Methods}

\subsection{Animals}

First, 39 rats were used Wistar (Rattusnorvegicus albinos), adults with a mean body mass of $275 \pm 25 \mathrm{~g}$, of $12 \pm 2$ weeks, coming from the animal house of the State University of Rio de Janeiro, which remained the animal house of the uni- 
versity, in cages grouped in Number 5, kept in a controlled environment with an average temperature of $26^{\circ} \mathrm{C}$, with light/dark cycle of 12 hours, getting plenty of water and balanced diet. This work was approved by the Ethics and Research Committee of the Catholic University of Petrópolis-RJ, protocol number 44/2010, and lasted seven days.

\subsection{Surgical Procedure}

The animals were initially weighed and then anesthetized with tiletamine in association with zolazepam (1:1) diluted in $5 \mathrm{ml}$ of distilled water are administered in the dose of $75 \mathrm{mg} / \mathrm{kg}$ with intramuscular injection in the left quadriceps. Fifteen minutes following anesthesia, the back of each animal was shaved. After local asepsis with clorexdine $2 \%$, there was the surgical incision $2.5 \mathrm{~cm}^{2}$ the dorsal.

\subsection{Experimental Groups}

The animals were randomly divided into 3 groups: GIC group $(n=13)$ : control group, non-irradiated by PDT; IGI-LVd group $(n=13)$ : underwent incision in the dorsal region of the green $2 \mathrm{~cm}^{2}$ and applying PDT (525 nm) per time 20 minutes; GIII LVM-group $\left(\mathrm{n}=13\right.$ ): subject to the dorsal incision $2 \mathrm{~cm}^{2}$ and the application of PDT red $(640 \mathrm{~nm})$ for 20 minutes time.

\subsection{Equipment Used}

The equipment used is the OEM PDT LED Machine SHHB Technology Co Ltd. manufacturer, composed of two cables: a green LED with a wavelength of 525 $\mathrm{nm}$ and a red LED with a wavelength of $640 \mathrm{~nm}$. The power used was 4 watts.

Therapy with LEDs started 24 hours after the surgical incision. The application of LED was performed at $90^{\circ}$ from the treatment area according to the law of Lambert's cosine without skin contact. The distance of the zone was under the lesion area such that the light emitted by the LED covering the entire wound. Treatment consisted of 1 session daily for 5 days, totaling 5 sessions, always held on the same day period.

On the 7th day of the experiment (24 hours after the fifth application of the LED), the animals were sacrificed by euthanasia and collected up through heat scalpel, a skin fragment backs of all animals in the corresponding area of the wound. The samples were placed in appropriate containers and properly identified, containing $20 \mathrm{ml}$ of $10 \%$ formaldehyde solution, to manufacture the blades.

\subsection{Preparation of the Blades}

For qualitative analysis of epithelial repair and healing after 24 hours of fixation, the samples were sent to the pathology laboratory for routine histological processing. Were embedded in paraffin, cut with a rotary microtome with $4 \mathrm{mi}$ crometers and stained with hematoxylin and eosin technique and Masson.

The slides were examined under a light microscope Celestrone for histologist, blindly. After review and tabulation of the data were made photomicrographs with digital camera attached to the microscope. 


\section{Results and Discussion}

Among the factors that influence healing, we can mention the contribution of nutrients, metabolism, blood circulation, cellular senescence, infection and formation of bacterial biofilm [3].

It was observed that in the control group were marked acute inflammation and composed of a large number of large infiltration of neutrophils and edema. Chronic inflammation was mild and insignificant. Keratin crust was present in all samples with mild epithelialization in the margins. Granulation tissue not completely filled and the wound area was constituted by young connective tissue, loose with moderate number of inflammatory cells, deposition of collagen and light (53\%), best observed by the Masson staining.

According to Pinto (2011), the first leukocytes to reach the site of injury are neutrophils, which have the function phagocytose and digest dead cells and microorganisms. They release enzymes that will attract other inflammatory cells and initiate the formation of granulation tissue. The increased presence of inflammatory cells indicates an extension of the inflammation time, more time to spend another step: repair [16].

According to Jorge and Dantas (2003), after a surgical incision, the space created by this, is immediately filled with clotted blood clot and this will dehydrate forming the crust covering the wound [17].

In the green LED group, it was found that acute moderate inflammation comprised of a number of neutrophils and moderate edema. Chronic inflammation was slight; however, in the group treated with PDT green, the amount of chronic inflammatory cells (monocytes, macrophages, lymphocytes, and plasma cells) in the granulation tissue was higher compared to non-irradiated group. The crust was also present in all animals, but the marginal epithelialization was slightly higher than in the control group, which considered moderate for quantification purposes. The granulation tissue in the wound completely filled nine animals (90\%), and collagen deposition in $90 \%$ of them being moderate in $40 \%$, and light in $40 \%$ of cases, which is best observed by the Masson's staining.

Corroborating with previous results, it is demonstrated a greater development of the granulation tissue in rats exposed to the LED compared to non exposed, and the epithelization at the wound margins and the formation of scars with better quality occurred with the red LED [14].

The results demonstrate the persistence of chronic inflammation that according Vinck et al. (2005), is characterized by increased proliferation of infiltrating fibroblasts and the production of blood vessels, especially capillaries, which explains the process of healing moderate and more collagen described by trichromic test compared with the control group [18].

According to Carvalho (2002), the granulation tissue starts to be formed by the fourth day after the injury and at this stage the new fibroblasts accumulated blend the neoformation of capillaries, starting the granulation tissue. Collagen is the major component of connective tissue scar. Collagen fibers are the most frequent in volume and space in connective tissue and in many cases appear grouped form- 
ing coiled bundles [19].

In the red LED group turned out that the acute inflammation was present with moderate influx of neutrophils (90\%) to mild (20\%). Edema was moderate in $40 \%$, $20 \%$ mild and $20 \%$ severe. Chronic inflammation was presented light but present throughout the analysis. Tissue crusts, as in the other groups were present in all animals, but to epithelialization the banks reached a larger area, which was considered severe for quantification purposes. Granulation tissue filled the whole wound in $100 \%$ of the sample, this group because I was more developed with less edema, inflammatory cells and increased collagen deposition when compared to the control groups and irradiated with green PDT.

Corroborating these findings, according to Pinto et al., Seung et al. and Trelles et al. $(2006 ; 2011)$ red GT, used after plastic surgery trauma, decreases the time resolution of side effects such as erythema, edema and hematomas in half to one-third of the time for its effective anti-inflammatory action [16] [20] [21].

For Pinto et al. $(2007 ; 2008$; 2011) with the use of PDT have been a significant decrease in wrinkles and increase in skin elasticity. Histological there is a significant increase in the amount of collagen and elastic fibers. Structurally examinations have shown that fibroblasts were highly activated, surrounded by abundant elastic fibers, collagen and presence of eosinophils [16] [22] [23].

Therefore, in relation to acute inflammation, the presence of neutrophils was higher in the control group compared to the group and may be stated that phototherapy with green and red PDT has anti-inflammatory effects and is more effective the red phototherapy. Chronic inflammation was similar in all groups, but responses were higher in the group treated by Red PDT. Tissue crust was present in all groups treated or not and epithelialization on the banks was higher in the treated groups, with a little more effectiveness with red PDT. Masson trichrome technique showed more collagen in the group treated by PDT red, but in all groups was positive.

\section{Conclusions}

It was concluded that PDT did not use collimated green $(525 \mathrm{~nm})$ and red (640 $\mathrm{nm}$ ) for 10 minutes' produced qualitative results in the formation of scar second intention (occurs when a wound margins presents apart and forms a large blood clot). The banks and scarring's better quality epitelization occurred at $640 \mathrm{~nm}$ (red), thus noting up a greater presence of collagen. Phototherapy not collimated $640 \mathrm{~nm}$ (red) resulted in better anti-inflammatory effects. Given these responses, with no clinical phototherapy collimated green $(525 \mathrm{~nm})$ and red $(640 \mathrm{~nm})$, it was noted that the benefit was possible to use, mainly with red LED, but the 20 minute's treatment time could be inefficient. For the future, a signal is controled by using a higher $\mathrm{N}$ followed by evaluation immune histochemical markers and tests by microscopy atomic force, and then followed by testing with different waves-length power to both PDT and PDT with photosensitive drug.

It is undeniable that PDT offers curative repair facilitation, since it offers therapeutic resources capable of accelerating this process, especially regarding the 
use of LEDs. Although the literature cites the benefits in the treatment of chronic diabetic foot ulcers and other conditions, this technology is still underutilized in clinical practice, and animal research should be expanded to promote further studies in this respect for PDT to consolidate its significant role to play in the new scenario of bacterial multiresistance [4] [24].

\section{Acknowledgements}

Thanks to the Center of Higher Education of Valença of Dom André Arcoverde Foundation.

\section{References}

[1] Alwan, A., Maclean, D.R., Riley, L.M., d'Espaignet, E.T., Mathers, C.D., Stevens, G.A. and Bettcher, D. (2010) Monitoring and Surveillance of Chronic Noncommunicable Diseases: Progress and Capacity in High Burden Countries. The Lancet, 376, 1861-1868. https://doi.org/10.1016/S0140-6736(10)61853-3

[2] Fang, R.C. and Galiano, R.D. (2009) Adjunctive Therapies in the Treatment of Osteomyelitis. Seminars in Plastic Surgery, 23, 141-147.

https://doi.org/10.1055/s-0029-1214166

[3] Panuncialman, J. and Falanga, V. (2010) Unusual Causes of Cutaneous Ulceration. Surgical Clinics of North America, 90, 1161-1180.

[4] Hamblin, M.R. (2016) Antimicrobial Photodynamic Inactivation: A Bright Newtechnique to Kill Resistant Microbes. Current Opinion in Microbiology, 33, 67-73. https://doi.org/10.1016/j.mib.2016.06.008

[5] Diretrizes da Sociedade Brasileira de Diabetes (2016) Parte 2: Complicações, Doenças Relacionadas e Decorrentes do Diabetes Mellitus. 137-214.

http://www.diabetes.org.br/sbdonline/images/docs/DIRETRIZES-SBD-2015-2016.p df

[6] Darlenski, R. and Fluhr, J.W. (2012) Photodynamic Therapy in Dermatology: Past, Present, and Future. Journal of Biomedical Optics, 18, Article ID: 061208. https://doi.org/10.1117/1.jbo.18.6.061208

[7] Kashef, N., Djavid, G.E., Siroosy, M., Khani, A.T., Zokai, F.H. and Fateh, M. (2011) Photodynamic Inactivation of Drug-Resistant Bacteria Isolated from Diabetic Foot Ulcers. Iranian Journal of Microbiology, 3, 36-41.

[8] Abrahamse, H. and Hamblin, M.R. (2016) New Photosensitizers for Photodynamic Therapy. Biochemical Journal, 473, 347-364. https://doi.org/10.1042/BJ20150942

[9] Lei, X., Liu, B. and Wu, J. (2015) A Clinical Study of Photodynamic Therapy for Chronic Skin Ulcersin Lower Limbs Infected with Pseudomonas aeruginosa. Archives of Dermatological Research, 307, 49-55. https://doi.org/10.1007/s00403-014-1520-4

[10] Sharma, M., Visai, L., Bragheri, F., Cristiani, I., Gupta, P.K. and Speziale, P. (2008) Toluidine Blue-Mediated Photodynamic Effects on Staphylococcal Biofilms. Antimicrobial Agents and Chemotherapy, 52, 299-305. https://doi.org/10.1128/AAC.00988-07

[11] Tardivo, J.P. and Baptista, M.S. (2009) Treatment of Osteomyelitis in the Feet of Diabetic Patients by Photodynamic Antimicrobial Chemotherapy. Photomedicine and Laser Surgery, 145-150. https://doi.org/10.1089/pho.2008.2252

[12] Tardivo, J.P., Adami, F., Correa, J.A., Pinhal, M.A.S. and Baptista, M.S. (2014) A Clinical Trial Testing the Efficacy of PDT in Preventing Amputation in Diabetic Pa- 
tients. Photodiagnosis and Photodynamic Therapy, 11, 342-350.

https://doi.org/10.1016/j.pdpdt.2014.04.007

[13] Abramovitis, W. and Arrozala, A.G.K. (2005) Light-Emitting Diode-Based Therapy. Skinmed, 4, 38-41. https://doi.org/10.1111/j.1540-9740.2005.03959.x

[14] Meyer, P.F., Araújo, H.G., Carvalho, M.G.F., Tatum, B.I.S., Fernandes, I.C.A., Ronzio, O.A. and Pinto, M.V.M. (2010) Avaliação dos efeitos do LED na cicatrização de feridas cutâneas em ratos Wistar. Fisioterapia Brasil, 11, 428-432.

[15] Failache, H. and Geido, D. (2006) Fonte de fototerapia em base a LEDs, Facultades de Ingeniería y Medicina Universidad de la República Del Uruguay. Montevidéu. http://uruguayescribe/fuente-de-luz-azul-para-el-tratamiento-de-la-hiperbilirrubine mia-neonatal

[16] Pinto, M.V.M. (2011) Fototerapia Aspectos Clínicos da Reabilitação. Editora Andreoli.

[17] Jorge, A.S. and Dantas, S.R.P.E. (2003) Abordagem multiprofissional do tratamento de feridas. Atheneu, São Paulo.

[18] Vinck, E.M., Cagnie, B.J., Cornelissen, M.J., Declercg, H.A. and Cambier, D.C. (2005) Green Light Emitting Diode Irradiation Enhances Fibroblast Growth Impaired by High Glucose Level. Photomed Laser Surg, 2, 167-171. https://doi.org/ 10.1089/pho.2005.23.167

[19] Carvalho, P.T.C. (2002) Análise da cicatrização de lesões cutâneas através da espectrofometria: Estudo experimental em ratos diabéticos [Dissertação]. Universidade de São Paulo, São Paulo.

[20] Seung, A., Park, K.H., Choi, J.W., Kwon, J.K., Doo, K.L., Mi, S.S., et al. (2007) A Prospective, Randomized, Placebo-Controlled, Double-Blinded, and Split-Face Clinical Study on LED Phototherapy for Skin Rejuvenation: Clinical, Profilometric, Histologic, Ultrastructural, and Biochemical Evaluations and Comparison of Three Different Treatment Settings. Journal of Photochemistry and Photobiology, 88, 51 67. https://doi.org/10.1016/j.jphotobiol.2007.04.008

[21] Trelles, A.M. and Allones, E.M. (2006) Red Light-Emitting Diode (LED) Therapy Accelerates Wound Healing Post-Blepharoplasty and Periocular Laser Ablative Resurfacing. Journal of Cosmetic and Laser Therapy, 8, 39-42. https://doi.org/10.1080/14764170600607731

[22] Pinto, M.V.M., Costa, D.A., Aguiar, J.L.N., Barauna, M.A., Silva, A.L.S., Biagini, A.P., et al. (2007) Análise do efeito da terapia laser de baixa intensidade e do controle doloroso na cicatrização da úlcera venosa. Revista Dor, 8, 1113-1137.

[23] Pinto, M.V.M., Costa, D.A., Rocha, L.L.V., Santos, H.R., Silva, A.L.S.S., Barbosa, L.G., et al. (2008) Estudo comparativo dos efeitos do Ga-As (904 nm, 150mW) laser e do ultra-som pulsado de $1 \mathrm{MHz}$ na inflamação do músculo tibial de ratos Wistar. Brazilian Archives of Biology and Technology, 51, 225-230.

[24] Bartoled, D. (2008) Light-Emitting Diodes (LEDs) in Dermatology. Seminars in Cutaneous Medicine and Surgery, 27, 227-238.

https://doi.org/10.1016/j.sder.2008.08.003 
Submit or recommend next manuscript to SCIRP and we will provide best service for you:

Accepting pre-submission inquiries through Email, Facebook, LinkedIn, Twitter, etc. A wide selection of journals (inclusive of 9 subjects, more than 200 journals)

Providing 24-hour high-quality service

User-friendly online submission system

Fair and swift peer-review system

Efficient typesetting and proofreading procedure

Display of the result of downloads and visits, as well as the number of cited articles Maximum dissemination of your research work

Submit your manuscript at: http://papersubmission.scirp.org/

Or contact mri@scirp.org 